\title{
Beta-amyloid increases the expression level of ATBF1 responsible for death in cultured cortical neurons
}

\author{
Cha-Gyun Jung ${ }^{1 *}$, Kyung-Ok Uhm¹, Yutaka Miura², Takashi Hosono ${ }^{1}$, Hirofumi Horike ${ }^{1}$, Kum Kum Khanna ${ }^{3}$, \\ Mi-Jeong Kim ${ }^{1}$ and Makoto Michikawa'
}

\begin{abstract}
Background: Recently, several lines of evidence have shown the aberrant expression of cell-cycle-related proteins and tumor suppressor proteins in vulnerable neurons of the Alzheimer's disease (AD) brain and transgenic mouse models of $A D$; these proteins are associated with various paradigms of neuronal death. It has been reported that ATBF1 induces cell cycle arrest associated with neuronal differentiation in the developing rat brain, and that gene is one of the candidate tumor suppressor genes for prostate and breast cancers in whose cells overexpressed ATBF1 induces cell cycle arrest. However, the involvement of ATBF1 in AD pathogenesis is as yet unknown.

Results: We found that ATBF1 was up-regulated in the brains of 17-month-old Tg2576 mice compared with those of age-matched wild-type mice. Moreover, our in vitro studies showed that A 1-42 and DNA-damaging drugs, namely, etoposide and homocysteine, increased the expression ATBF1 level in primary rat cortical neurons, whereas the knockdown of ATBF1 in these neurons protected against neuronal death induced by A $\beta 1-42$, etoposide, and homocysteine, indicating that ATBF1 mediates neuronal death in response to these substances. In addition, we found that ATBF1-mediated neuronal death is dependent on ataxia-telangiectasia mutated (ATM) because the blockage of ATM activity by treatment with ATM inhibitors, caffeine and KU55933, abolished ATBF1 function in neuronal death. Furthermore, AB1-42 phosphorylates ATM, and ATBF1 interacts with phosphorylated ATM.
\end{abstract}

Conclusions: To the best of our knowledge, this is the first report that A 1-42 and DNA-damaging drugs increased the ATBF1 expression level in primary rat cortical neurons; this increase, in turn, may activate ATM signaling responsible for neuronal death through the binding of ATBF1 to phosphorylated ATM. ATBF1 may therefore be a suitable target for therapeutic intervention of AD.

\section{Background}

Alzheimer's disease (AD), a progressive neurodegenerative disorder of the elderly, is associated with a chronic loss of synapses and neuronal death, and is characterized by the presence of parenchymal deposits of amyloid- $\beta$ peptides $(A \beta)$, the major protein component of senile plaques $[1,2]$. Accumulation of $A \beta$ in the brain is associated with disease-causing inherited variants of the amyloid precursor protein (APP) [3], presenilin 1 (PS1) [4], presenilin 2 (PS2) [5], and apoplipoprotein E

\footnotetext{
* Correspondence: jung@ncgg.go.jp

'Department of Alzheimer's Disease Research, Research Institute, National Center for Geriatrics and Gerontology (NCGG), 35, Morioka, Obu, Aichi 4748511, Japan

Full list of author information is available at the end of the article
}

(APOE) [6] genes, and an increased extracellular $\mathrm{A} \beta$ level is a major cause of neuronal death in AD. In addition to genetic evidence that $\mathrm{A} \beta$ promotes neuronal degeneration and death in vivo $[7,8]$, in vitro studies show that $A \beta$ aggregates rapidly induce neuronal death by necrosis or apoptosis $[9,10]$, and $A \beta$-induced neurotoxicity involves oxidative stress, inflammation, and perturbation of calcium homeostasis [1]. However, the mechanisms by which neuronal degeneration and death occur in $A D$ and whether they are induced by $A \beta$ are not completely understood.

One focus in the mechanism of neuronal death in $\mathrm{AD}$ is the aberrant expression of cell-cycle-related proteins, such as cdc2, cdk4, cyclin B1, and cyclin D, which mediate cell cycle progression, in vulnerable neurons of the

\section{Biomed Central}


AD brain [11-14]; these molecules play essential roles in neuronal death associated with various paradigms of neuronal death [15]. In addition to cell cycle progression molecules, a number of cell cycle inhibitors, such as p16 and p27 [13,16], and tumor suppressor proteins such as p53 and BRCA1 $[17,18]$ are also increased in levels in the AD brain. In addition to the human $A D$ brain, the increased expression levels of cell-cyclerelated proteins were also found in transgenic mouse models of AD $[19,20]$. Although it is unclear why cellcycle-related proteins show increased in levels in the $\mathrm{AD}$ brain and $\mathrm{AD}$ mouse models, one possibility is that DNA damage induced by $A \beta$ may increase the levels of or activate these molecules. Indeed, DNA damage was found in the $\mathrm{AD}$ brain, and $\mathrm{A} \beta$ increases Cdc25A [21], Cdk4, and p53 [22] levels in primary rat neurons resulting in neuronal death. Recently, Kruman et al. have reported that cultured postmitotic cortical neurons exposed to $A \beta$ undergo apoptosis that is dependent on tumor suppressor factor ataxia-telangiectasia mutated (ATM) activity, whereas treatment with caffeine, which is an ATM inhibitor, can exert a neuroprotective effect on cultured neurons exposed to $A \beta$ [22]. In this context, ATM appears to potentiate neuronal apoptosis.

AT-motif binding factor 1 (ATBF1) is a $404 \mathrm{kDa}$ transcription factor that contains 4 homeodomains and 23 zinc-finger motifs [23] involved in transcription regulations and protein-protein interactions [24]. We previously reported that ATBF1 is highly expressed in postmitotic neurons but not in neural progenitor cells, and it induces cell cycle arrest associated with neuronal differentiation in the developing rat brain [25]. We also found that sublocalization of ATBF1 is regulated by phospatidylinositol-3 (PI3) kinase including ATM [25], indicating that ATBF1 is one of the targets of ATM. Indeed, ATM phosphorylates ATBF1 at Ser1180 in HEK293T cells exposed to 10-Gy radiation [26]. ATBF1 also interacts with $\mathrm{p} 53$ to activate the $\mathrm{p} 21^{\text {Waf1/Cip1 }}$ promoter to trigger cell cycle arrest [27]. It has also been reported that the ATBF1 gene is one of the candidate tumor suppressor genes for prostate and breast cancers in whose cells overexpressed ATBF1 induces cell cycle arrest $[28,29]$. However, the involvement of ATBF1 in $\mathrm{AD}$ pathogenesis is as yet unknown.

In this study, we investigated whether ATBF1 expression is altered in the brains of Tg2576 mice similarly to other cell-cycle-related molecules, and we found an upregulated ATBF1 expression in the brains of Tg2576 mice compared with those of age-matched wild-type mice. Moreover, our in vitro studies showed that $A \beta$ and DNA-damaging drugs, namely, etoposide and homocysteine, increased the ATBF1 expression level in primary rat cortical neurons; this increase, in turn, may activate ATM signaling responsible for neuronal death through the binding of ATBF1 to phosphorylated ATM.

\section{Results}

ATBF1 was up-regulated in the brains of 17-month-old Tg2576 mice compared with those of age-matched wildtype mice

We first investigated whether ATBF1 expression is altered in the brains of Tg2576 mice overexpressing human APP with the Swedish mutation. Total proteins were extracted from whole brains of 10- and 17-monthold Tg2576 and age-matched wild-type mice, and subjected to Western blot analysis. We found that the ATBF1 expression level in the brains of 17-month-old wild-type mice was lower than that in the brains of 10month-old wild-type mice. However, ATBF1 expression was significantly up-regulated in 17-month-old Tg2576 mice compared with age-matched wild-type mice, whereas there was no significant difference between Tg2576 and wild-type mice at the age of 10 months (Figure 1).

\section{$A \beta 1-42$ and DNA-damaging drugs, etoposide and homocysteine, increased ATBF1 expression level in cultured rat cortical neurons}

In Tg2576 brains, the accumulation of $\mathrm{A} \beta$ occurs from 15 to 23 months but is not observed in appreciable amounts until 12 months [30]. Therefore, we hypothesized that an increase in ATBF1 expression level in the brains of 17month-old Tg2576 mice is due to an increase in A $\beta$ level. To test this hypothesis, we determined by Western blot analysis the protein expression levels of ATBF1 and p53, which play a key role in the regulation of cell viability in response to DNA-damaging drugs in many cell types including neurons, in cultured rat cortical neurons treated with $10 \mu \mathrm{M} A \beta 1-42$ for $16 \mathrm{~h}$. The $\mathrm{A} \beta 1-42$ peptide used in our experiments was largely monomer (see "Additional file $1^{\prime \prime)}$. We observed that $A \beta 1-42$ significantly increased ATBF1 and p53 protein expression levels in these cells (Figure 2A). A previous study showed that the expression level of ATBF1 is increased in gastric cancer cells exposed to mitomycin-C, which can induce DNA damage in many cell types [31]. This finding suggests that DNA damage might increase ATBF1 expression level because $A \beta$ can also induce neuronal apoptosis through oxidative DNA damage. Therefore, we treated cultured cortical neurons with two different DNA-damaging drugs, etoposide and homocysteine, which are used commonly as DNA-damaging drugs for many cells types including neurons, and we found that these two drugs significantly increased ATBF1 and 553 protein expression levels (Figure 2A). Next, we measured the expression levels of ATBF1 mRNA in cultured cortical neurons treated with $A \beta 1-42$ at an indicated dose by semiquantitative real-time PCR analysis. As 


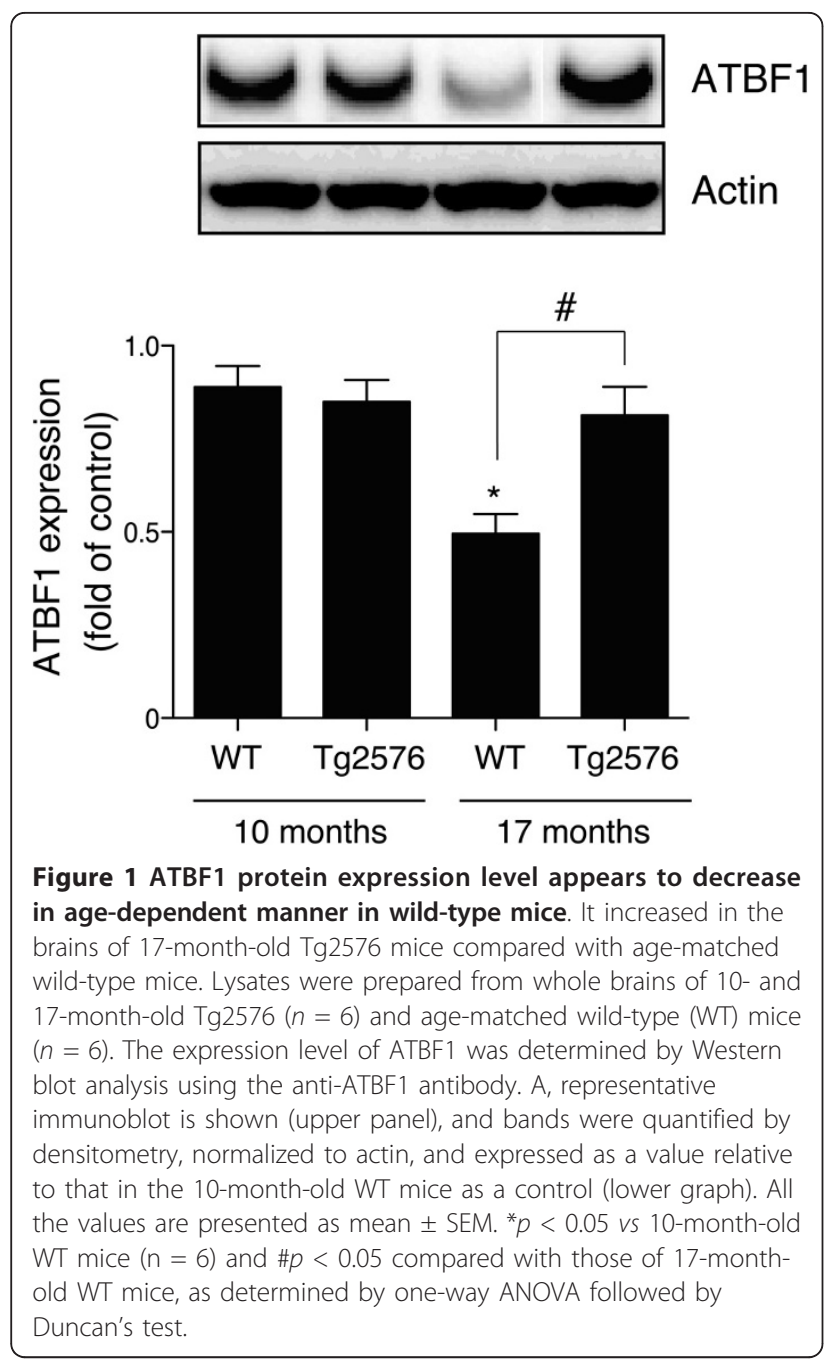

shown in Figure $2 B$, treatment with $A \beta 1-42$ significantly increased ATBF1 mRNA expression level in a dose-dependent manner compared with the control, and etoposide and homocysteine also increased ATBF1 mRNA expression level (Figure 2C). These findings indicate that an increase in ATBF1 protein expression level induced by A $\beta 1-42$, etoposide, and homocysteine is caused by an increase in ATBF1 gene expression level.

\section{Knockdown of ATBF1 in cultured cortical neurons} protected against A 1 1-42-, etoposide-, and homocysteineinduced neurotoxicity

A 1 1-42, etoposide, and homocysteine induce death of cultured cortical neurons in vitro [22]. Next, we examined whether ATBF1 mediates neuronal death after treatment with $A \beta 1-42$, etoposide, and homocysteine. For this purpose, we first decreased the ATBF1 expression level in primary cortical neurons by ATBF1 siRNA transfection. The cells were transfected with ATBF1 siRNA-1 or control siRNA, as described in
"Experimental Procedures". Forty-eight hours after transfection, the ATBF1 protein expression level was determined by Western blot analysis using an antiATBF1 antibody. As shown in Figures 3A and 3C, the transfection of ATBF1 siRNA-1 decreased the ATBF1 protein level by about $75 \%$ in cultured cortical neurons compared with control siRNA transfection. This finding indicates that endogenous ATBF1 can be efficiently knocked down in these cells by transfection of ATBF1 siRNA-1. Next, we determined the effects of ATBF1 knockdown on neuronal survival against $A \beta 1-42-$, etoposide-, and homocysteine-induced neurotoxicity. Cultured cortical neurons transfected with ATBF1 siRNA1 or control siRNA were treated with $A \beta 1-42$ at an indicated dose, $1 \mu \mathrm{M}$ etoposide, or $250 \mu \mathrm{M}$ homocysteine for $16 \mathrm{~h}$. Cell viability was then assessed using a CellTitle-Glo luminescent cell viability assay kit. We were able to detect differences in cell viability only by ATBF1 siRNA-1 transfection compared with control siRNA transfection. The percentage of surviving neurons decreased in control-siRNA-transfected cells after the treatment with A 1 1-42, etoposide, or homocysteine. However, the percentage of surviving neurons increased in ATBF1-siRNA-1-transfected cells compared with control-siRNA-transfected cells after the treatment with $A \beta 1-42$ (Figure $3 \mathrm{~B}$ ), etoposide, or homocysteine (Figure 3D). These findings indicate that ATBF1 could mediate neuronal death in response to the treatment with $A \beta 1-42$, etoposide, or homocysteine. We also determined the effects of another ATBF1 siRNA (ATBF1-siRNA-2) on neuronal survival against $A \beta 1-42$-induced neurotoxicity, and obtained similar result (Additional file 2). Therefore, we used ATBF1 siRNA-1 to ATBF1 knockdown for the following experiments.

\section{ATBF1 mediated apoptotic function in cultured cortical neurons against $A \beta 1-42$-induced neurotoxicity}

To determine whether apoptosis is responsible for the survival of cultured cortical neurons with decreased ATBF1 expression levels, we analyzed DNA breaks by terminal deoxynucleotidyl transferase-mediated dUTP nick-end labeling (TUNEL) assay of ATBF1-siRNA- and control-siRNA-transfected cells after A 1-42 treatment. Figure 4A shows representative images of TUNEL-positive cells and total nuclei. The treatment of control siRNA-transfected cells with $A \beta 1-42$ resulted in a significant increase in the number of TUNEL-positive cells compared with nontreatment (Figure 4A). However, the percentage of TUNEL-positive cells among ATBF1siRNA-transfected cells treated with $A \beta 1-42$ was lower than that among control-siRNA-transfected cells (Figure $4 \mathrm{~A})$, indicating that the knockdown of ATBF1 significantly reduced the extent of A $\beta 1-42$-induced apoptosis. 
A
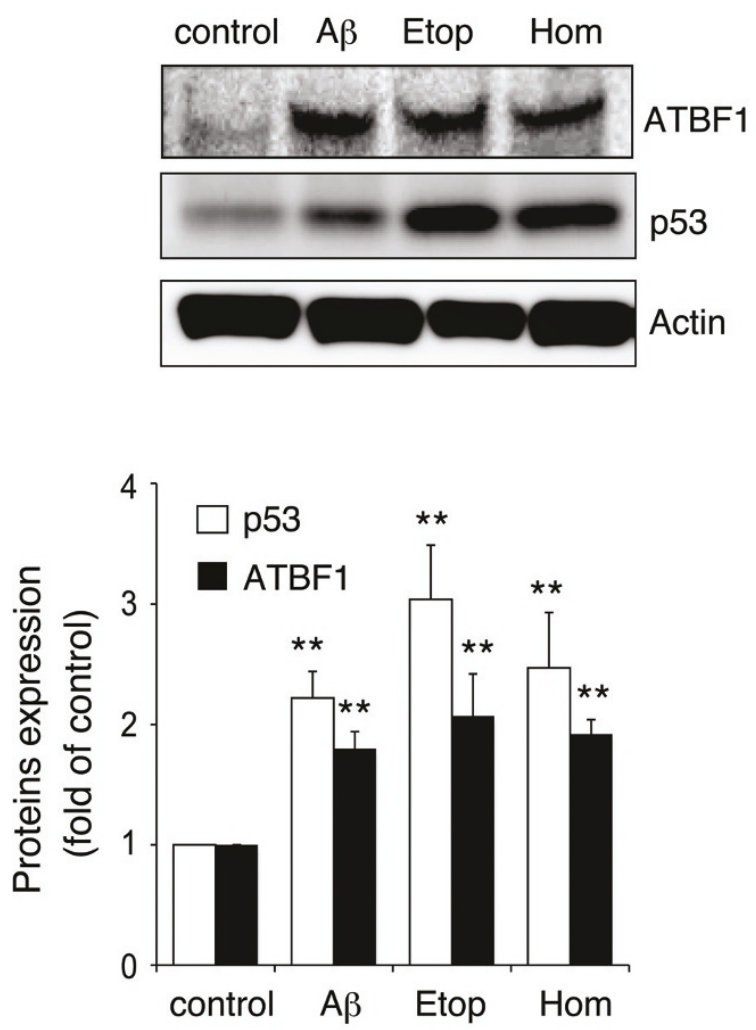

B

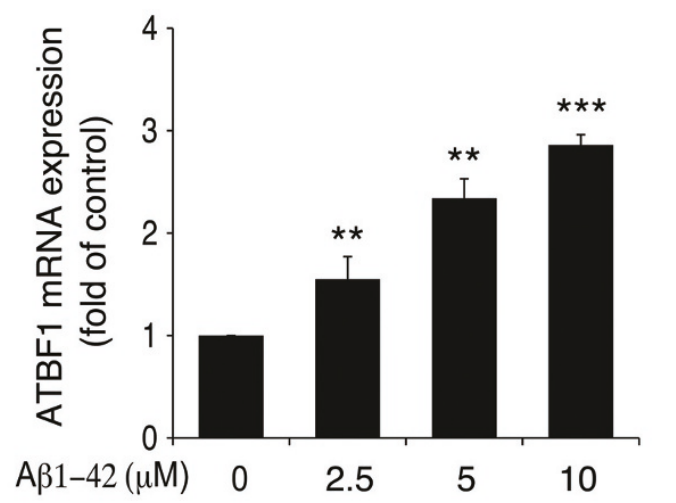

C

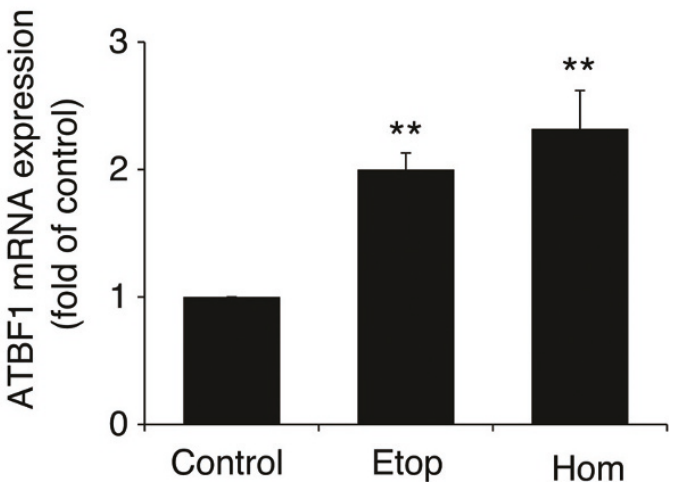

Figure 2 ATBF1 protein and mRNA expression levels increased in primary cortical neurons after treatment with A 1 1-42 and DNAdamaging drugs, namely, etoposide (Etop) and homocysteine (Hom). A, primary cortical neurons were seeded at a density of $1 \times 10^{6}$ cells/ $\mathrm{ml}$ in poly-d-lysine-coated $60 \mathrm{~mm}$ culture dishes. Three days after plating, the cells were treated for $16 \mathrm{~h}$ with $10 \mu \mathrm{M}$ A $31-42,1 \mu \mathrm{M}$ etoposide, or $250 \mathrm{MM}$ homocysteine, and the cells were then harvested. The expression levels of ATBF1 and p53 were determined by Western blot analysis using the anti-ATBF1 and anti-p53 antibodies. A, a representative immunoblot is shown (upper panel), and bands were quantified by densitometry, normalized to actin, and expressed as a value relative to that of the control (lower panel). B and C, primary cortical neurons were treated for $16 \mathrm{~h}$ with $0,2.5$, 5, or $10 \mu \mathrm{M}$ Aß1-42 (B), or $250 \mu \mathrm{M}$ homocysteine or $1 \mu \mathrm{M}$ etoposide (C). ATBF mRNA expression level was determined by real-time PCR analysis. The expression level of ATBF1 mRNA was normalized to the corresponding amount of actin mRNA and expressed as a value relative to that of the control. All the values are presented as the mean \pm SEM of three independent experiments. ${ }^{*} p<$ $0.05,{ }^{* *} p<0.01,{ }^{* * *} p<0.001$ vs control, as determined by Student's t-test.

The knockdown of ATBF1 alone showed no significant increase in the percentage of TUNEL-positive cells (Figure 4A). To confirm these findings, we performed a similar experiment, and caspase-3/7 activity was determined using a Caspase-Glo 3/7 assay kit. It has been reported that $A \beta$ may lead to the induction of caspase3 -mediated pathways that are involved in oxidative stress [32]. The treatment of control siRNA-transfected cells with $A \beta 1-42$ increased the activity of caspase- $3 / 7$ compared with nontreatment (Figure 4B). However, a decreased activity of caspase-3/7 was detected in ATBF1-siRNA-transfected cells treated with A $\beta 1-42$, indicating that ATBF1 is at least one vital component for the activation of caspase-3/7 in cultured cortical neurons after $A \beta 1-42$ treatment.

\section{Overexpression of ATBF1 itself in primary cortical neurons did not induce apoptosis}

Next, we examined whether overexpression of ATBF1 itself induces apoptosis in cultured cortical neurons. The cells were transfected with HA-tagged full-length human ATBF1 cDNA. Twenty-four hours after transfection, we performed TUNEL assay, and then counted TUNEL-positive cells among HA-ATBF1-transfected 
C

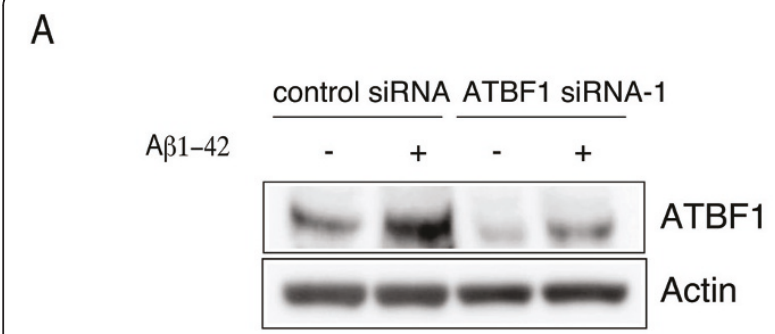

B

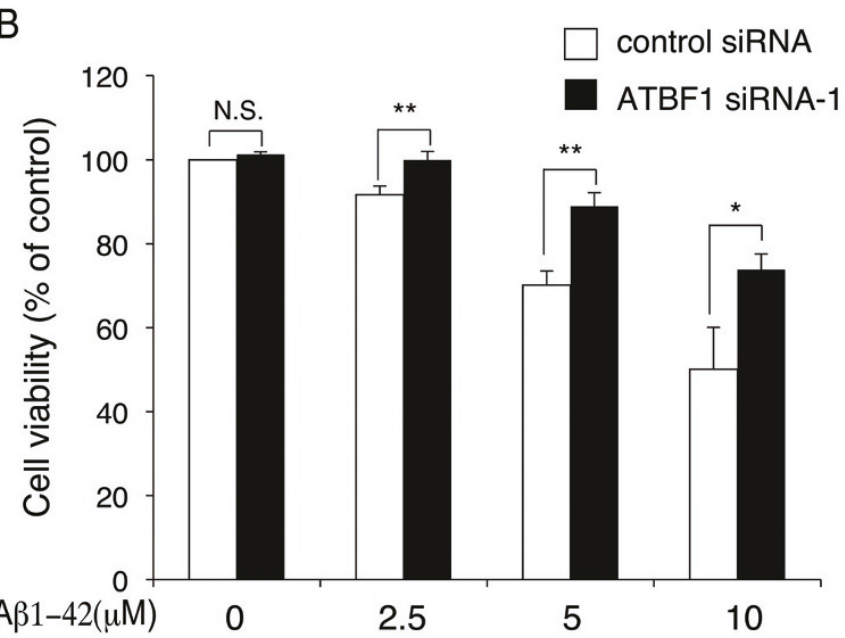

control siRNA ATBF1 siRNA-1

control Etop Hom control Etop Hom

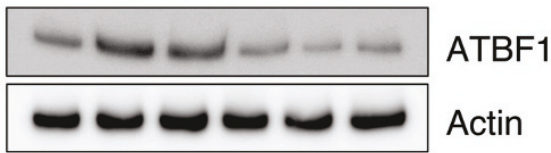

D

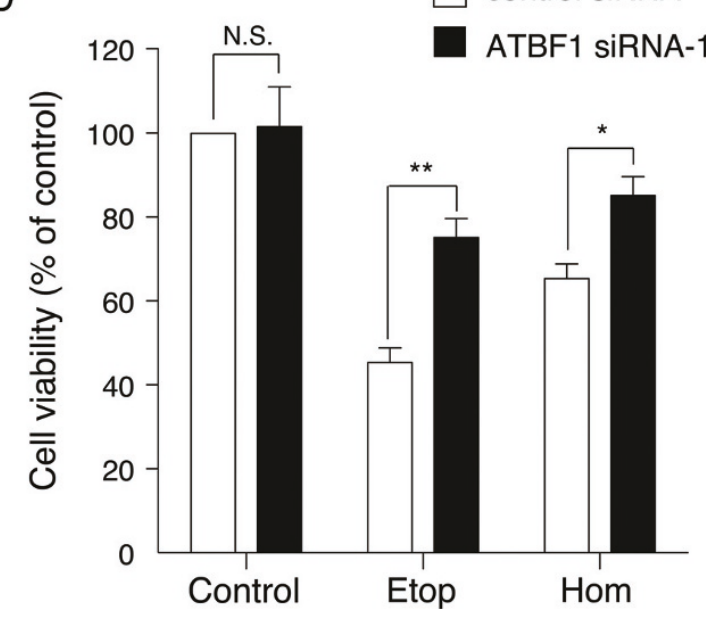

Figure 3 ATBF1 knockdown decreases the viability of primary cortical neurons upon treatment with $A \beta 1-42$, etoposide (Etop), or homocysteine (Hom). A and C, knockdown of ATBF1 in primary cortical neurons. Primary cortical neurons were transfected with ATBF1 siRNA-1 or control siRNA for $48 \mathrm{~h}$. After transfection, the cells were then incubated in the presence or absence of $10 \mu \mathrm{M} A \beta 1-42$ (A), $1 \mu \mathrm{M}$ etoposide (C), or $250 \mu \mathrm{M}$ homocysteine (C) for $16 \mathrm{~h}$. The expression levels of ATBF1 and actin were determined by Western blot analysis using the anti-ATBF1 and anti-actin antibodies. B and D, primary cortical neurons were seeded at a density of $1 \times 10^{6} \mathrm{cell} / \mathrm{s} / \mathrm{ml}$ in poly-d-lysine-coated 96-well plates. Three days after plating, cells were transfected with ATBF1 siRNA-1 or control siRNA for $48 \mathrm{~h}$, and the cells were then treated with $0,2.5,5$, or 10 $\mu \mathrm{M}$ AB 1-42 (B), $1 \mu \mathrm{M}$ etoposide (D), or $250 \mu \mathrm{M}$ homocysteine (D) for $16 \mathrm{~h}$. Cell viability was determined using a CellTiter-Glo luminescent cell viability assay kit and is shown as a percentage of surviving cells. All the values are presented as the mean \pm SEM of three independent experiments. ${ }^{*} p<0.05,{ }^{* *} p<0.01$ vs control siRNA treatment. N.S., not significant, as determined by Student's t-test.

cells. We found that cells transfected with HA-ATBF1 were largely TUNEL-negative $(95.2 \pm 1.2 \%)$ (Figure 5$)$. This finding is consistent with our previous finding that overexpression of ATBF1 in Neuro 2A cells (mouse neuroblastoma cell line) by transfection of the HAATBF1 expression vector did not induce apoptosis [25].

\section{ATBF1-mediated neuronal death after A $\beta 1-42$ treatment depended on ATM}

Recent findings have shown that the ATM signaling pathway is essential for $A \beta$-induced neuronal death in vitro and in vivo, and treatment with caffeine, an inhibitor of ATM, protects cultured cortical neurons against apoptosis induced by A $\beta 1-42$ [22]. Our previous data have shown that the nuclear localization of ATBF1 is suppressed by treatment with caffeine, indicating that ATBF1 function could be regulated by ATM [25]. Moreover, it has also been reported that the ATBF1 gene is one of the target genes of ATM, which phosphorylates ATBF1 at Ser1180 [26]. Therefore, we examined whether ATBF1-mediated neuronal death after A $\beta 1-42$ treatment is dependent on ATM. To determine whether caffeine can protect against neuronal death induced by $A \beta 1-42$, we analyzed the effects of caffeine on cell viability (Figure 6A) and caspase-3/7 activity (Figure 6B). Cultured cortical neurons were pretreated with $10 \mu \mathrm{M}$ caffeine for $1 \mathrm{~h}$ and subsequently treated with $2.5 \mu \mathrm{M}$ and $5 \mu \mathrm{M} \mathrm{A} \beta 1-42$ for $16 \mathrm{~h}$. The cells were then assessed for cell viability and caspase-3/7 activity using CellTitle-Glo luminescent cell viability assay and Caspase-Glo ${ }^{\mathrm{TM}} 3 / 7$ assay kits, respectively. As shown in Figures $6 \mathrm{~A}$ and $6 \mathrm{~B}$, treatment with caffeine decreased the number of dead cells treated with $A \beta 1-42$ (Figure 6A) and decreased caspase-3/7 activity (Figure $6 \mathrm{~B})$ compared with the nontreatment control. We also tested the effect of KU55933, a specific inhibitor of ATM [33], on cell viability. As shown in Additional file 3A, treatment with KU55933 decreased the number of 


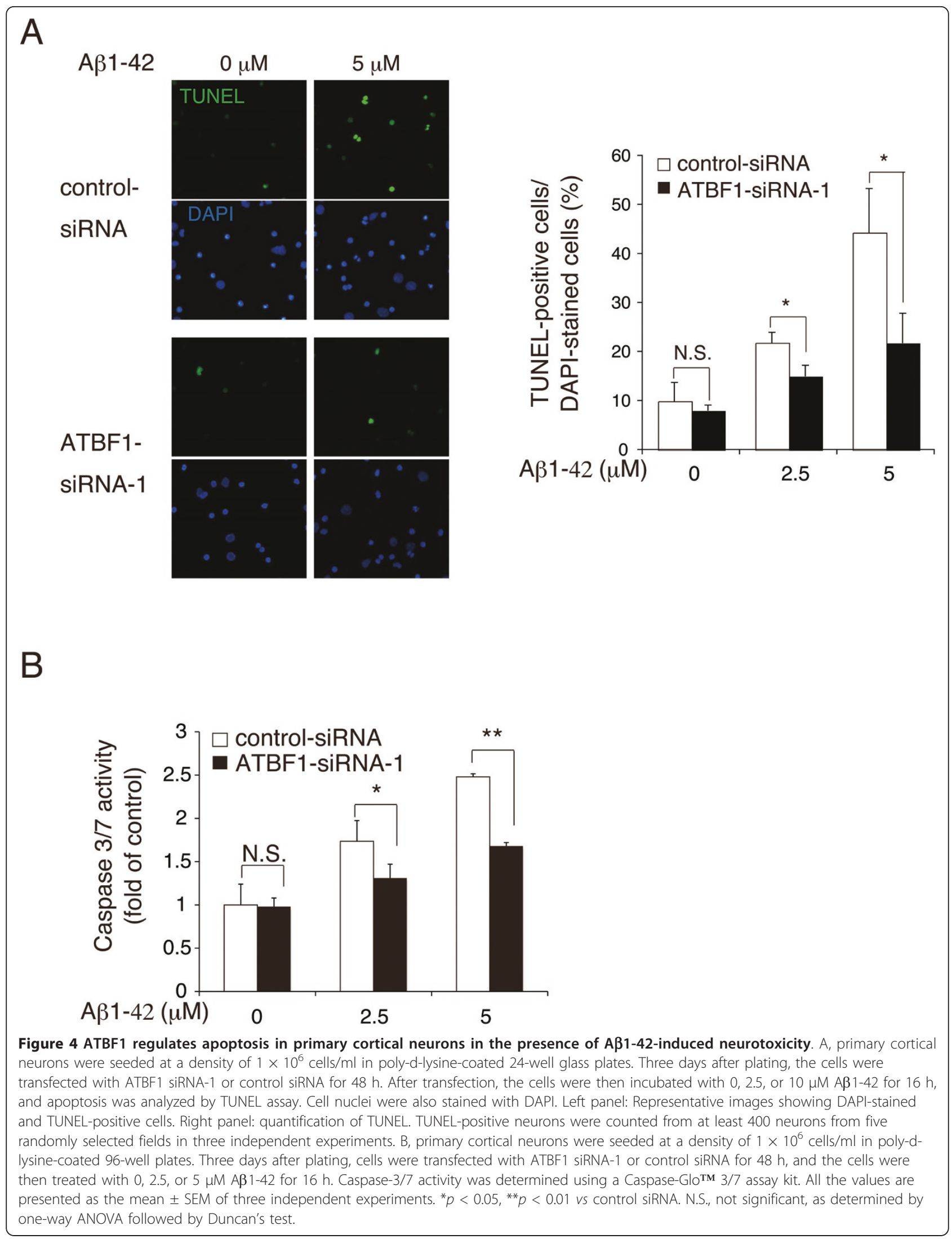




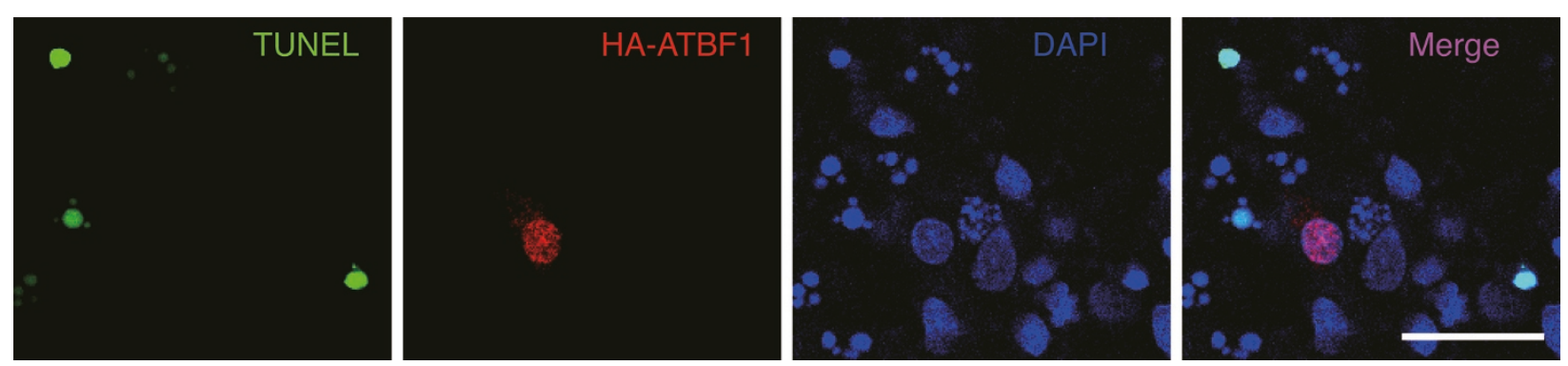

Figure 5 Overexpression of HA-tagged ATBF1 itself in primary cortical neurons did not induce apoptosis. TUNEL of primary cortical neurons transfected with HA-tagged ATBF1. The cells were transiently transfected with HA-tagged ATBF1. Twenty-four hours after transfection, TUNEL was performed, and then the cells were stained with the anti-HA antibody to detect transfected HA-ATBF1. Scale bars: $25 \mu$ m.

dead cells treated with $A \beta 1-42$, etoposide, or homocysteine at concentration as low as $1 \mu \mathrm{M}$. These findings indicated that treatment with ATM inhibitors protect against A $\beta 1$-42-, etoposide-, or homocysteine-induced neuronal death. Next, we assessed the effect of siRNAmediated ATBF1 knockdown on A $\beta 1$-42-induced neuronal death after treatment with caffeine or KU55933. As shown in Figure 6C and Additional file 3, there are no significant differences in the percentage of survival between ATBF1 siRNA-transfected neurons with treatment of caffeine or KU55933 and those without treatment with caffeine or KU55933. These findings indicate that ATBF1 is required for neuronal death in response to $A \beta 1-42$ treatment, which could be dependent on ATM signaling.

\section{ATBF1 interacted with phosphorylated ATM}

It is not known whether $A \beta 1-42$ can induce the phosphorylation of ATM in cultured cortical neurons. We therefore analyzed the effect of $A \beta 1-42$ on the expression level of phosphorylated ATM (pATM) at Ser1981, as an indicator of ATM activation, in cultured cortical neurons. Cultured cortical neurons were treated with 10 $\mu \mathrm{M} \mathrm{A} \beta 1-42$ for $3 \mathrm{~h}$ or with $1 \mu \mathrm{M}$ etoposide for $1 \mathrm{~h}$ as the positive control, and PATM expression level was determined by Western blot analysis using a specific antibody to ATM at Ser1981. We found an increase in pATM levels after the treatments with $A \beta 1-42$ and etoposide (Figure 7A). To determine whether ATBF1 interacts with pATM, coimmunoprecipitation analysis was performed. Cultured cortical neurons were treated with $10 \mu \mathrm{M} \mathrm{A} \beta 1-42$ for $3 \mathrm{~h}$ or $1 \mu \mathrm{M}$ etoposide for $1 \mathrm{~h}$, and then subjected to immunoprecipitation with anti-ATBF1 antibody-conjugated Protein $\mathrm{G}$ beads followed by immunoblotting with the anti-pATM antibody. As shown in Figure 7B, ATBF1 interacted with pATM after treatment with $A \beta 1-42$ or etoposide. Our findings suggest that ATBF1 expression was enhanced by $A \beta 1-42$ and DNA-damaging drugs (etoposide and homocysteine) and increased the expression level of ATBF1, which in turn activated ATM signaling responsible for neuronal death through the binding of ATBF1 to pATM.

\section{ATM was required for ATBF1 to activate the p21 promoter}

To determine the functional relationship between ATBF1 and ATM, we carried out p21 (Waf1/Cip1) promoter assay using ATM $(+/+)$ and ATM (-/-) human fibroblast cells. ATM has been shown to play a role in the induction of DNA double strand breaks to arrest the cell cycle via activation of p53, and ATBF1 activates the p21 promoter in collaboration with p53 [27]. As shown in Figure 8, irradiation with X-ray increased the p21 promoter activity in ATM $(+/+)$ cells, but not in ATM $(-/-)$ cells, which is consistent with a previous finding that p21 expression is not changed in ATM $(-/-)$ cells treated with the DNA-damaging drug etoposide [34]. Overexpression of ATBF1 increased the p21 promoter activity in ATM $(+/+)$ cells, but not in ATM (-/-) cells. The combination of $\mathrm{X}$-ray irradiation and overexpression of ATBF1 in ATM $(+/+)$ cells synergistically increased p21 promoter activity. Importantly, this effect of ATBF1 on $\mathrm{p} 21$ promoter activity was abolished in ATM (-/-) cells. This finding indicates that ATBF1 increases p21 promoter activity in an ATM-dependent manner.

\section{Discussion}

Recently, cell-cycle-related molecules have been implicated as required components in the mechanisms underlying neuronal death in response to injury, stroke, and neurodegenerative diseases including AD [35-38] and transgenic mouse models of $\operatorname{AD}[19,20]$. We have previously reported that ATBF1 is highly expressed in postmitotic neurons but not in neural progenitor cells in the developing rat brain, and that its mRNA expression level is highest in the embryonic day 12.5 (E12.5) brain [25]. Moreover, the overexpression of ATBF1 induces cell cycle arrest in mouse neuroblastoma, human prostate cancer, and human breast cancer cell 


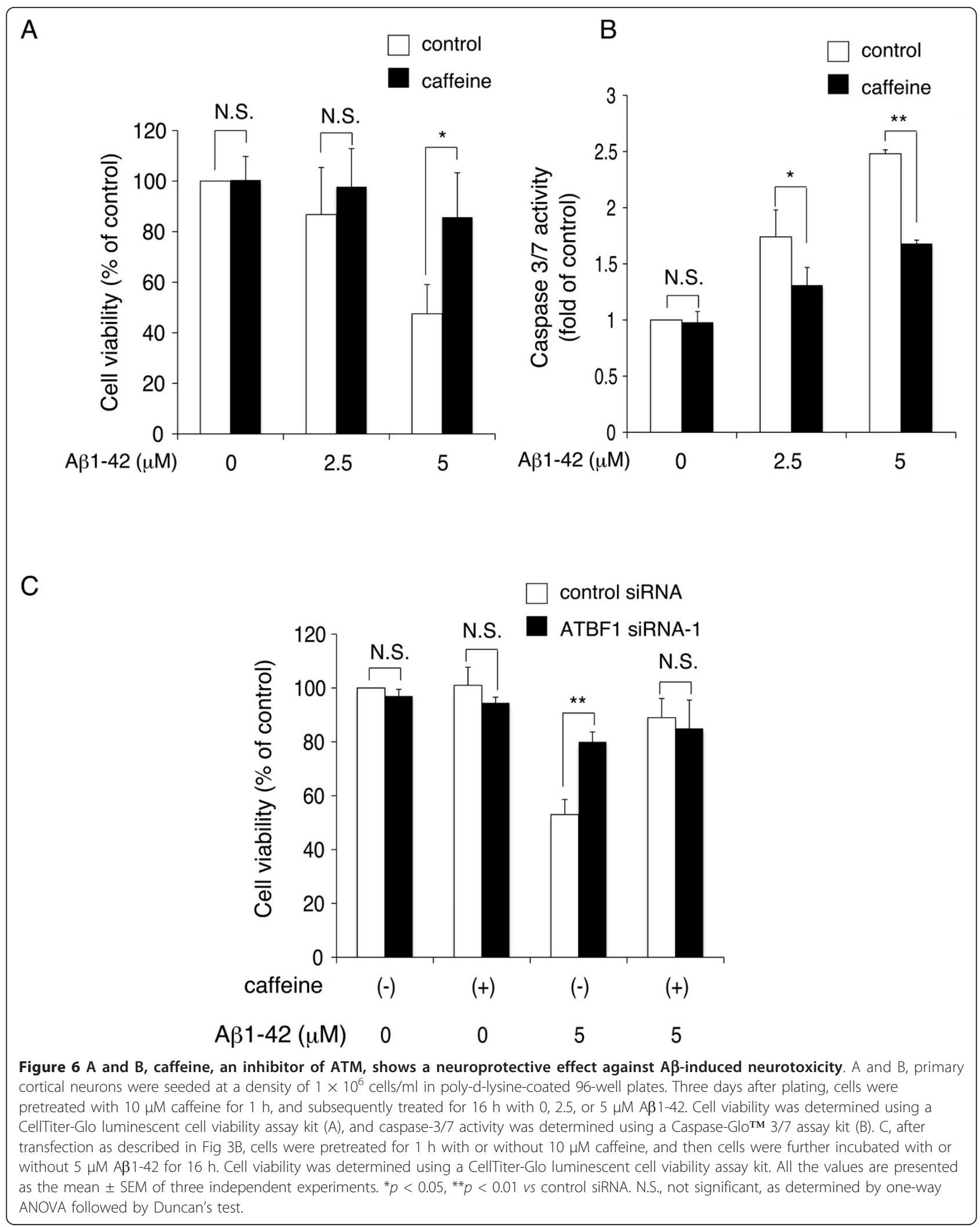




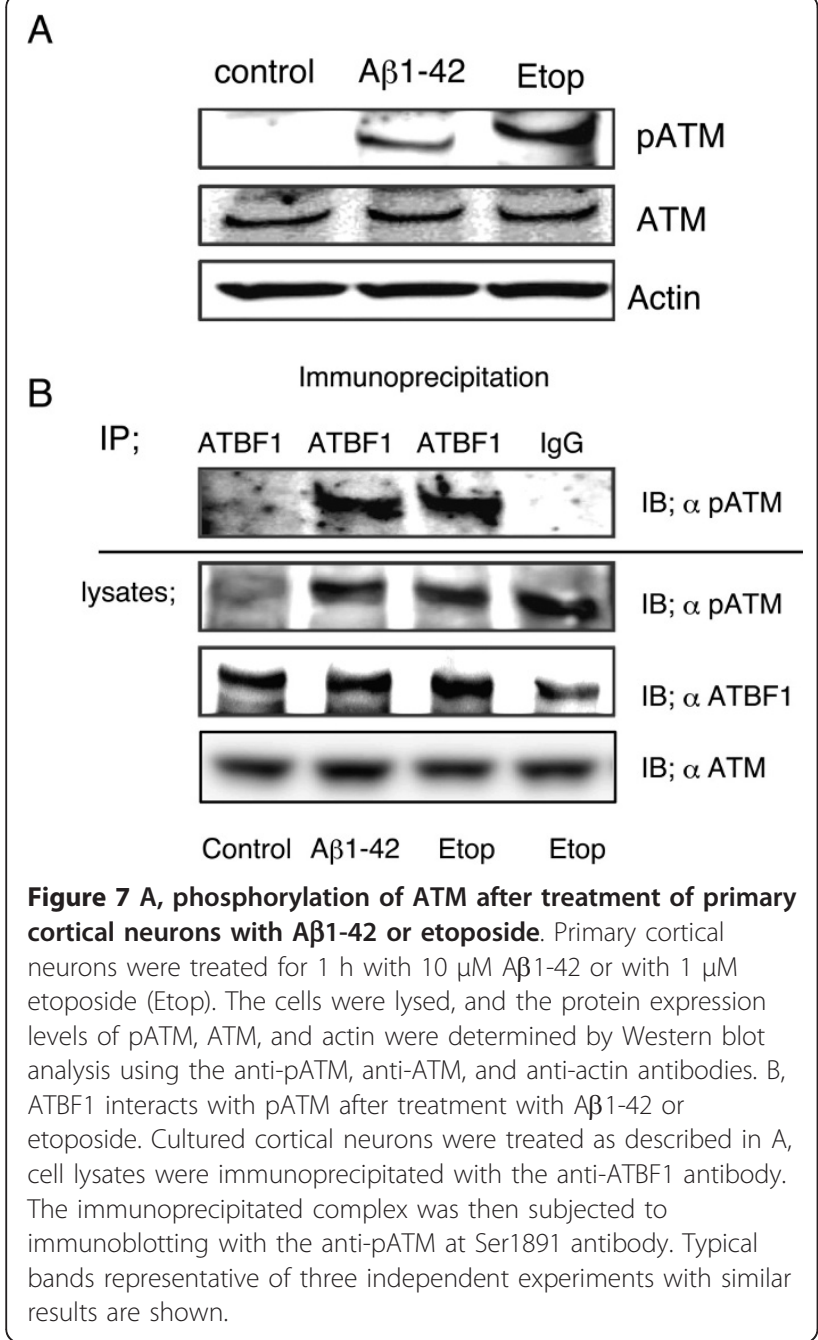

lines $[25,28,29]$. These findings suggest that ATBF1 may play critical roles in cell cycle arrest and proliferation. In the present study, we found that the ATBF1 expression level in the brains of 17-month-old wild-type mice decreased compared with that in the brains of 10 month-old wild-type mice. This finding is consistent with our previous finding that ATBF1 mRNA expression level gradually decreases with increasing age in the rat brain [25]. However, ATBF1 expression was up-regulated in the brains of 17-month-old Tg2576 mice compared with that in the brains of age-matched wild-type mice. In Tg2576 mice, diffuse plaques appear after 12 months, and their amount gradually increases with age [30]. Therefore, we considered that the increase in ATBF1 expression level was due to $A \beta$, and we found that the treatment with $A \beta 1-42$ significantly increased the expression levels of ATBF1 mRNA and protein in cultured rat cortical neurons. The increase in ATBF1 expression level in the brains of 17 -month-old Tg2576 mice could be triggered by the accumulation of

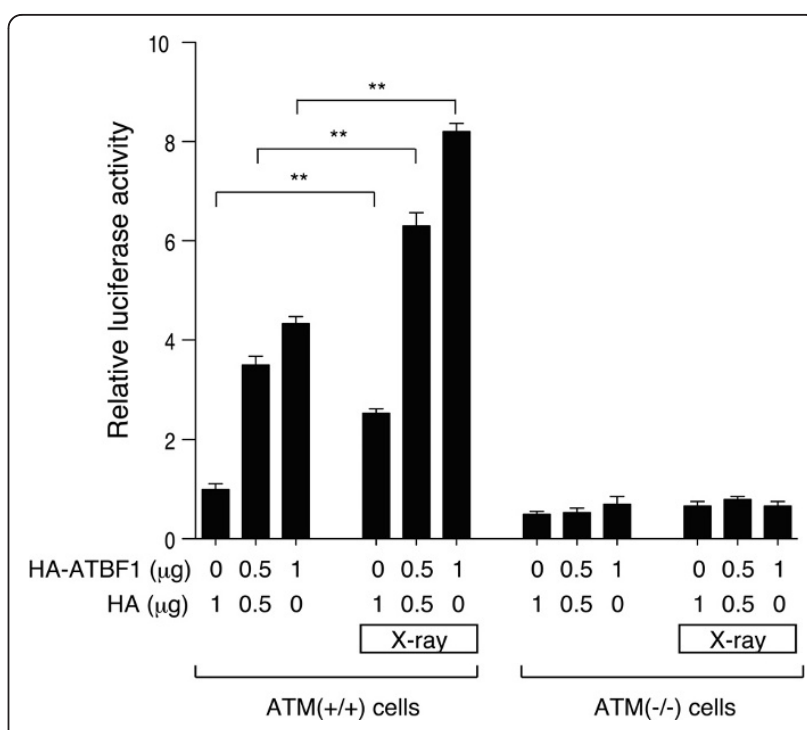

Figure 8 Effect of ATBF1 on activation of p21 promoter in Xray-irradiated ATM $(+/+)$ and ATM (-/) cells. ATM $(+/+)$ and ATM $(-/-)$ cells were transfected with p21 promoter-luciferase, pRL-TKluciferase (as an internal control), and an indicated dose of HAATBF1 vector or $\mathrm{pCl}-\mathrm{HA}$ vector as a control. After $24 \mathrm{~h}$, cells were irradiated with a $2.5 \mathrm{~Gy}$ X-ray, and then luciferase activity was measured after $12 \mathrm{~h}$. All the values are presented as the mean \pm SEM of three independent experiments. ${ }^{* *} p<0.01$ vs not irradiated. N.S., not significant, as determined by Mann-Whitney U-test with Bonferroni Correction.

extracellular $A \beta$ similar to the $A \beta$-mediated increase in ATBF1 expression level observed in cultured cortical neurons. In addition, the reason why ATBF1 remains increased in 17-month-old Tg2576 mice could be that $A \beta$ induces neurons to re-enter the cell cycle and ATBF1 prevents this process from occurring.

$A \beta$ induces oxidative DNA damage. A previous study showed that the expression level of ATBF1 is increased in gastric cancer cells treated with mitomycin-C, which can induce DNA damage in many cell types [31]. This suggests that DNA damage might increase ATBF1 expression level. We, therefore, also examined whether treatment with DNA-damaging drugs, namely, etoposide and homocysteine, affects ATBF1 expression. Here, we found that these DNA-damaging drugs significantly increased the expression levels of ATBF1 mRNA and protein in cultured rat cortical neurons. These findings suggest that the up-regulated ATBF1 expression observed in our in vivo and in vitro experiments could be due to DNA damage induced by $A \beta$.

It has been reported that the consequences of DNA damage are the expression of cell-cycle-related proteins $[22,39,40]$ and activation of the family of phosphatidylinositol-3 (PI3)-kinases that include the ATM protein, which is involved in the regulation of cell cycle and apoptosis by the phosphorylation of many downstream 
substrates [41-43]. Therefore, one possibility is that ATM could constitute a common pathway activated in neuronal apoptosis after DNA damage. Recently, we have found that ATM induces ATBF1 expression during retinoicacid-induced neuronal differentiation of P19 cells by the activation and binding of CREB to a CRE consensus site located in the ATBF1 promoter (unpublished data). It has also been reported that the ATBF1 gene is one of the target genes of ATM that phosphorylates ATBF1 at Ser1180 [26]. These observations suggest that the activation of ATM highly correlates with the function and expression of ATBF1 as a gene regulatory factor. In this study, we observed that treatment with A 1-42 and etoposide rapidly posphorylates ATM at Ser 1981, and that ATBF1 interacts with pATM in cultured cortical neurons. Taken together, ATM activation induced by $A \beta$ and DNA-damaging drugs may induce ATBF1 expression.

In this study, we also examined the effect of ATBF1 on neuronal death and apoptosis induced by $A \beta 1-42$, etoposide, and homocysteine in cultured cortical neurons, and we found that the knockdown of ATBF1 by ATBF1 siRNA transfection significantly reduced the extent of cell death and apoptosis induced by $A \beta 1-42$, etoposide, homocysteine. In addition, the knockdown of ATBF1 attenuated the activation of caspase-3/7. These findings suggest that the increased ATBF1 expression level may mediate apoptotic function in cultured cortical neurons against $A \beta 1-42$-induced neurotoxicity. It has been reported that $A \beta$ and DNA-damaging drugs induce the expression and activation of p53 which plays an important role in promoting apoptosis in cultured neurons $[22,44]$. Therefore, the increased ATBF1 expression level might simultaneously activate p53 to promote cell death, because ATBF1 interacts with p53 [27]. We also found in this study that ATBF1-mediated neuronal death is dependent on ATM signals because the blockage of ATM by treatment with ATM inhibitors, caffeine and KU55933, abolished ATBF1 functions in neuronal death. This finding is in agreement with our previous finding that caffeine treatment inhibits the translocalization of ATBF1 to the nucleus in P19 cells [25]. Further studies are necessary to characterize the role of ATBF1 in $\mathrm{AD}$ pathogenesis such as whether ATBF1 expression is altered in the $\mathrm{AD}$ brain.

\section{Conclusions}

In conclusion, the increase in ATBF1 expression level observed in the brain of 17-month-old Tg2576 mice compared with age-matched wild-type mice could be caused by DNA damage induced by A $\beta 1-42$, which in turn activates the ATM signaling responsible for neuronal death, indicating that ATBF1 plays an important role in neuronal death in response to $A \beta 1-42$, etoposide, and homocystein, and it may be a useful target in the development of drugs to suppress the neuronal death induced by $A \beta 1-42$.

\section{Methods \\ Tg2576 mice}

Female Tg2576 mice, an animal model of amyloid deposition, overexpressing human APP695 with the Swedish mutation K670N/M671, were obtained from Taconic (Germantown, NY). All the experiments were performed in accordance with the Guidelines for Animal Experiments of the Animal Experimentation Committee of the National Center for Geriatrics and Gerontology.

\section{Cell cultures}

Cerebral cortical neurons were obtained from E17 Sprague-Dawley rats and cultured as described previously [45]. Briefly, embryonic brains were dissected, stripped of meninges, and minced with forceps. The minced tissue was incubated in $0.25 \%$ trypsin and $2 \mathrm{mg} / \mathrm{ml}$ DNase I in phosphate-buffered saline (PBS) at $37^{\circ} \mathrm{C}$ for $15 \mathrm{~min}$. The fragments were then dissociated into single cells by pipetting. The dissociated cells were suspended in DMEM/F-12 medium (50:50\%) containing $\mathrm{N}_{2}$ supplements and 7.5\% bovine albumin fraction $\mathrm{V}$, and plated onto poly-d-lysinecoated $60 \mathrm{~mm}$ dishes at a density of $1 \times 10^{6} / \mathrm{ml}$. These cells were used on day 4 of plating for further experiments. The immortalized fibroblast cell line AT22IJE-T was originally established from primary ataxia-telangiectasia (AT) patient fibroblasts [46]. The cells were transfected with either the pEBS7 or pEGS7-YZ ATM vector to obtain AT22IJE-T/pEBS7 (ATM -/-) and AT22IJE-T/YZ5 (ATM $+/+$ ) cells, respectively [47]. Cells were maintained in DMEM containing 15\% fetal bovine serum (FBS), $2 \mathrm{mM}$ glutamine, $100 \mu \mathrm{g} / \mathrm{ml}$ hygromycin $\mathrm{B}, 100 \mathrm{U} / \mathrm{ml}$ penicillin, and $0.1 \mathrm{mg} / \mathrm{ml}$ streptomycin.

\section{RNA extraction and real-time PCR}

Total RNA was isolated from primary cortical neurons using an RNeasy plus mini kit (Qiagen, Valencia, CA) following the manufacturer's instructions. Reverse transcription was performed using $1 \mu \mathrm{g}$ of total RNA using a PrimeScript RT reagent kit (Takara, Tokyo, Japan). Real-time PCR was carried out using the SYBR Premix Ex Taq system and Thermal Cycler Dice Real-Time system (Takara). The expression of the ATBF1 gene was normalized with the corresponding amount of actin mRNA using the comparative threshold cycle method following the manufacturer's protocols. Amplification was performed using the following primers (sense and antisense): ATBF1 (5'-CAAAACTTCTGCTGCCCTTC3 ' and 5'-GGCTTGTCTCAAGGTGC-TTC-3') and actin (5'-CATCCGTAAAGACCTCTATGCCAAC-3' and 5'-ATGGA-GCCACCGATCCACA-3'). 


\section{$A \beta 1-42$ treatment}

The synthetic $A \beta 1-42$ peptide was purchased from Peptide Institute (Osaka, Japan), dissolved in $0.1 \% \mathrm{NH}_{3}$ to the final concentration of $1 \mathrm{mM}$, and stored at $-80^{\circ} \mathrm{C}$ until use. To confirm the state of the $A \beta 1-42$ peptide, we performed Western blot analysis. Briefly, a stored A $\beta 1-42$ peptide was subjected to $16 \%$ Tris-Tricine Gel (Invitrogen) electrophoresis and transferred to polyvinylidene difluoride (PVDF) membranes (Millipore, Billerica, MA). These membranes were incubated with a primary antibody against mouse monoclonal human $A \beta$ (6E10; Covance, Emeyryville, CA). For detection, the membrane was incubated with a horseradish-peroxidase-conjugated Ig anti-mouse antibody. Immunoreaction signals were visualized with ECL ${ }^{\mathrm{TM}}$ or ECL Plus ${ }^{\mathrm{TM}}$ Western blotting detection reagent (GE Healthcare, Piscataway, NJ) and exposed to the LAS-3000 Mini Bioimaging Analyzer System (FUJIFILM Co., Tokyo, Japan).

\section{Western blot analysis}

The cells were washed with PBS and homogenized in lysis buffer (10 mM Tris- $\mathrm{HCl}$ (pH 7.4), $150 \mathrm{mM} \mathrm{NaCl}, 1$ mM EDTA, 1\% Triton X-100) containing a protease inhibitor cocktail (Roche, Mannheim, Germany). The homogenates were rocked at $4^{\circ} \mathrm{C}$ for $30 \mathrm{~min}$ and centrifuged at $13,000 \times g$ at $4^{\circ} \mathrm{C}$ for $30 \mathrm{~min}$ to remove cell debris. The resulting supernatant was collected and protein concentration was determined using a BCA protein assay kit (Pierce, Rockford, IL). Equal amounts of protein were subjected to $7.5 \%$ or $5-20 \%$ gradient SDS polyacrylamide gel electrophoresis, and separated products were transferred to PVDF membranes. These membranes were then blocked with $5 \%$ skim milk in $10 \mathrm{mM}$ Tris- $\mathrm{HCl}(\mathrm{pH} 7.5), 150 \mathrm{mM} \mathrm{NaCl}$, and $0.1 \%$ Tween 20 for $1 \mathrm{~h}$ at room temperature or overnight at $4^{\circ} \mathrm{C}$. These membranes were incubated with primary antibodies, namely, the anti-ATBF1 (AT-6) antibody (1:1000; MBL, Nagoya, Japan), anti-p53 antibody (1:1000; Cell Signaling, Cambridge, UK), anti-ATM antibody (1:1000; Gene Tex, Irvine, CA), anti-ATM kinase pS1981 antibody (1:1000; Rockland, Gilbertsville, PA), or anti-actin antibody (1:2,000; Sigma, Saint Louis, MO). The membranes were washed, and then incubated with the appropriate secondary antibody conjugated to horseradish peroxidase. Immunoreaction signals were visualized with ECL $^{\mathrm{TM}}$ or ECL Plus ${ }^{\mathrm{TM}}$ Western blotting detection reagent and exposed to the LAS-3000 Mini Bio-imaging Analyzer System. Signal intensity was determined using MultiGauge software (FUJIFILM).

\section{RNA interference}

Endogenous ATBF1 was knocked down using predesigned Stealth ${ }^{\mathrm{TM}}$ siRNA against ATBF1 (ATBF1 siRNA) and Stealth siRNA negative control (control siRNA) from Invitrogen (Carlsbad, CA). The ATBF1 siRNAs sequences are as follows: ATBF1-siRNA-1 sense (5'UAC ACU GGU CAG ACC ACU GUC CUU G-3') and antisense (5'-CAA GGA CAG UGG UCU GAC CAG UGU -3'). ATBF1-siRNA-2 sense (5'- UAC ACU GGU CAG ACC ACU GUC CUU G-3') and antisense (5'TAC ACT GGT CAG ACC ACT GTC CTT G-3'). The primary cultured neurons were transiently transfected with 50 nM ATBF1 siRNA or with control siRNA using Lipofectamine RNAiMAX (Invitrogen) in accordance with the manufacturer's instructions. The knockdown effects were examined after $48 \mathrm{~h}$ of incubation. The cultures were then processed for Western blot analysis, cell viability analysis and terminal deoxynucleotidyl transferase-mediated dUTP nick-end labeling (TUNEL) assay 16 $h$ after $A \beta 1-42$ treatment.

\section{Cell viability analysis}

Neuronal viability was evaluated by CellTiter-Glo luminescent cell viability assay (Promega, Madison, WI), which is a method to determine the number of viable cells in culture based on the quantitation of ATP present, which indicates the presence of metabolically active cells. Briefly, primary cortical neurons were seeded onto poly-d-lysine-coated 96 -well plates, and incubated for $72 \mathrm{~h}$. For the ATBF1 knockdown experiment, the cells were transfected with ATBF1 siRNA or with control siRNA for $48 \mathrm{~h}$ as described above, cells were then treated with $A \beta 1-42$, etoposide, or homocysteine at indicated doses for $16 \mathrm{~h}$. After treatment, a volume of CellTiter-Glo Reagent was added to each well equal to the volume of cell culture medium. Then, the contents were mixed for 2 min on a shaker to induce cell lysis and the plates were incubated at room temperature for $10 \mathrm{~min}$ in the dark. Cellular luminescence intensity was measured using a GLOMAX 96-microplate luminometer (Promega).

\section{Plasmid constructs}

The ATBF1 expression vector of an $11 \mathrm{~kb}$ full-length human cDNA [23] was inserted into the $\mathrm{pCI}$ vector (Promega) with an HA-tagged sequence at the 5'-terminus of the inserted sequence (HA-ATBF1) [25]. The 2.4 $\mathrm{kb}$ fragment upstream from the TATA-box of the human p21 (Waf1/Cip1) genomic fragment was subcloned into the basic luciferase reporter $\mathrm{pGV}-\mathrm{B}$ vector (Toyo Ink Co., Ltd., Tokyo, Japan) [48].

\section{TUNEL assay}

Apoptosis was assessed by TUNEL using an ApopTag Fluorescein Direct In Situ Apoptosis Detection kit in accordance with the manufacturer's instructions (Chemicon, Temecula, CA). Briefly, cells were fixed with $1 \%$ paraformaldehyde in PBS for $10 \mathrm{~min}$ at room temperature 
and permeabilized in EtOH:acetic acid (2:1) for $5 \mathrm{~min}$ at $-20^{\circ} \mathrm{C}$. Cells were then washed with PBS. Fluorescein-conjugated nucleotide and TdT enzyme were added to the cells, which were then incubated for $1 \mathrm{~h}$ at $37^{\circ} \mathrm{C}$. Nuclei were stained with DAPI. Images were obtained using an AX70 fluorescence microscope (Olympus). The percentage of apoptotic cells was determined as the ratio of the number of DAPITUNEL-double-positive cells with respect to the total number of DAPI-positive cells. For the overexpression of ATBF1 in cultured cortical neurons, the neurons were transiently transfected with $0.5 \mu \mathrm{g}$ HA-ATBF1 using FuGENE HD (Roche) in accordance with the manufacturer's instructions. Twenty-four hours after transfection, TUNEL was performed as described in above. After TUNEL, the neurons were incubated with the primary antibody against HA-tag (MBL) for $1 \mathrm{~h}$ at RT. The secondary antibody was Alexa-594-conjugated goat anti-rabbit IgG (Molecular Probes). Images were obtained using an AX70 fluorescence microscope (Olympus).

\section{Caspase-3/7 activity assay}

Caspase-3/7 activity was assayed using a Caspase-Glo ${ }^{\mathrm{TM}}$ $3 / 7$ assay kit (Promega), in accordence with the manufacturer's instructions. Briefly, primary cortical neurons were seeded on 96-well plates at a density of $1 \times 10^{6}$ cells/ml. After 3 days, the cells were treated with $A \beta 1$ 42 or DNA-damaging drugs. Caspase-Glo ${ }^{\mathrm{TM}}$ 3/7 reagent was then added to each well, and the plates were incubated at room temperature for $1 \mathrm{~h}$. Cellular luminescence was measured using a GLOMAX 96-microplate luminometer (Promega).

\section{Immunoprecipitation}

Primary cortical neurons were grown in $10 \mathrm{~cm}$ dishes. After reaching 50-70\% confluence, the cells were treated with $10 \mu \mathrm{M} A \beta 1-42$ or $1 \mu \mathrm{M}$ etoposide for an indicated time. After incubation, the cells were washed twice with PBS, lysed in $1 \mathrm{ml}$ of lysis buffer $(10 \mathrm{mM}$ Tris- $\mathrm{HCl}$ (pH 7.4), $150 \mathrm{mM} \mathrm{NaCl}, 1 \mathrm{mM}$ EDTA, 1\% Triton X-100, 50 $\mathrm{mM} \mathrm{NaF}$, and $100 \mathrm{uM}$ sodium orthovanadate) containing protease inhibitor cocktail, and centrifuged at 13,000 $\times g$ at $4^{\circ} \mathrm{C}$ for $20 \mathrm{~min}$. The resulting supernatant was immunoprecipitated overnight with a specific antibody against ATBF1 (AT-6) in the presence of protein G beads (Pierce) at $4{ }^{\circ} \mathrm{C}$. The immune complexes were washed four times with lysis buffer. The samples were subjected to $5-20 \%$ gradient SDS polyacrylamide ge electrophoresis, and separated products were transferred to a PVDF membrane and subjected to immunoblotting with a specific antibody against phosphorylated-ATM (pATM) at Ser 1981.

\section{X-ray irradiation and p21 promoter assay}

ATM $(+/+)$ and ATM (-/-) cells were transfected with p21 promoter-luciferase, pRL-TK-luciferase (as an internal control), and an indicated dose of the HA-ATBF1 vector or PCI-HA vector as the control using Lipofectamine 2000 (Invitrogen) in accordance with manufacturer's instructions. After $24 \mathrm{~h}$, the cells were irradiated with X-ray at 2.5 Gy using a Softex M-80WE X-ray generator (SOFTEX, Japan) operating at $80 \mathrm{kv}$ and $10 \mathrm{~mA}$ for $25 \mathrm{~min}$ with a copper shield. Nonirradiated dells were used as control. After $12 \mathrm{~h}$, luciferase activity was measured using the Dual Luciferase Reporter Assay system (Promega) in accordance with the manufacturer's instructions.

\section{Statistical analysis}

Statistical analysis was performed using a statistical package, GraphPad prism software (GraphPad Software, San Diego, CA). All values are presented as the mean \pm SEM of at least three independent experiments.

\section{Additional material}

Additional file 1: Western blot analysis of $A \beta 1-42$ peptide used in our experiments. The stored $A \beta 1-42$ peptide was diluted with culture medium to the final concentration of $5 \mu \mathrm{M}$, and then 0.5 (lane 1), 1 (lane 2), or $2.5 \mu \mathrm{l}$ (lane 3) was loaded to $16 \%$ Tris-Tricine gel and probed with the monoclonal antibody $6 \mathrm{E} 10$ (recognizing residues 1-17 of $A \beta$ ).

Additional file 2: Effect of another ATBF1 siRNA (ATBF1 siRNA-2) on the viability of primary cortical neurons upon treatment with $A \beta 1$ 42. A, Primary cortical neurons were transfected with ATBF1 siRNA-2 or control siRNA for $48 \mathrm{~h}$. After transfection, the cells were then incubated

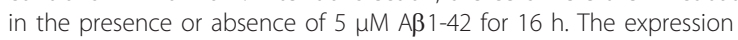
levels of ATBF1 and actin were determined by Western blot analysis using the anti-ATBF1 and anti-actin antibodies. B, After transfection as described in Figure $3 B$, the cells were treated with or without $5 \mu \mathrm{M} \mathrm{A \beta 1-}$ 42 for 16 h. Cell viability was determined using a CellTiter-Glo luminescent cell viability assay kit and is shown as a percentage of surviving cells. All the values are presented as the mean \pm SEM of three independent experiments. ${ }^{*} p<0.01$ vs control siRNA treatment. N.S., not significant, as determined by Student's $t$-test.

Additional file 3: A, KU55933, a specific ATM inhibitor, shows a neuroprotective effect against $A \beta$ 1-42-, etoposide-, and homocysteine-induced neurotoxicity. Primary cortical neurons were seeded at a density of $1 \times 10^{6}$ cells $/ \mathrm{ml}$ in poly-d-lysine-coated 96-well plates. Three days after plating, cells were pretreated with $0,1,5$, or 10 $\mu \mathrm{M} \mathrm{KU} 55933$ for $1 \mathrm{~h}$, and subsequently treated for $16 \mathrm{~h}$ with $5 \mu \mathrm{M}$ A $\beta 1$ 42, $1 \mu \mathrm{M}$ etoposide (Etop), or $250 \mu \mathrm{M}$ homocysteine (Hom). Cell viability was determined using a CellTiter-Glo luminescent cell viability assay kit. B, after transfection as described in Figure 3B, cells were pretreated for 1

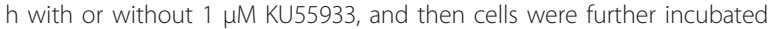
with or without $5 \mu \mathrm{M} A \beta 1-42$ for $16 \mathrm{~h}$. Cell viability was determined using a CellTiter-Glo luminescent cell viability assay kit. All the values are presented as the mean \pm SEM of three independent experiments. ${ }^{*} p<$ 0.001 vs control siRNA. N.S., not significant, as determined by one-way ANOVA followed by Duncan's test.

\section{Abbreviations}

ATBF1: AT-motif binding factor-1; $A \beta$ : Amyloid- $\beta$ peptide; AD: Alzheimer's disease; APP: Amyloid precursor protein; PS: presenilin; APOE: 
apoplipoprotein E; ATM: Ataxia-telangiectasia mutated; pATM: phosphorylated ATM; PI3K: phospatidylinositol-3 kinase; TUNEL: Terminal deoxynucleotidyl transferase-mediated dUTP nick-end labeling.

\section{Acknowledgements}

We thank Eri Arata for technical assistance in Western blot analysis. We thank Makoto Nakanishi for providing the p21 (Waf1/Cip1) promoter DNA fragment. This work was supported by a Grant-in-Aid for Scientific Research (C) from the Ministry of Education, Culture, Sports, Science and Technology of Japan (CGJ) and a grant from the Japan Health Sciences Foundation for the Research on Publicly Essential Drugs and Medical Devices (MM, KHC1 104) and a grant from The Research Funding for Longevity Sciences (21-A11) from National Center for Geriatrics and Gerontology (NCGG) (CGJ and MM), Japan and a Grant-in-Aid from the Japan Science and Technology Agency (YM).

\section{Author details}

'Department of Alzheimer's Disease Research, Research Institute, National Center for Geriatrics and Gerontology (NCGG), 35, Morioka, Obu, Aichi 4748511, Japan. ${ }^{2}$ Department of Molecular Neurobiology, Graduate School of Medical Sciences, Nagoya City University, Nagoya, 467-8601, Japan. ${ }^{3}$ Queensland Institute of Medical Research and University of Queensland Centre, for Clinical Research, Brisbane 4029, Queensland, Australia.

\section{Authors' contributions}

CGJ designed this study, carried out major parts of the experiments, and drafted the manuscript. KOU prepared primary cortical neurons. $\mathrm{YM}, \mathrm{TH}, \mathrm{HH}$, and MJK carried out the experiments. KKK provided comments on the manuscript. MM participated in the design of the study and in drafting the manuscript.

All authors have read and approved the final manuscript

\section{Competing interests}

The authors declare that they have no competing interests.

Received: 22 October 2010 Accepted: 5 July 2011 Published: 5 July 2011

\section{References}

1. Selkoe DJ: Alzheimer's disease: genes, proteins, and therapy. Physiol Rev 2001, 81:741-766.

2. Tanzi RE, Bertram L: Twenty years of the Alzheimer's disease amyloid hypothesis: a genetic perspective. Cell 2005, 120:545-555.

3. Goate A, Chartier-Harlin MC, Mullan M, Brown J, Crawford F, Fidani L, Giuffra L, Haynes A, Irving N, James $L$, et al: Segregation of a missense mutation in the amyloid precursor protein gene with familial Alzheimer's disease. Nature 1991, 349:704-706.

4. Sherrington R, Rogaev El, Liang Y, Rogaeva EA, Levesque G, Ikeda M, Chi H, Lin $C$, Li G, Holman K, et al: Cloning of a gene bearing missense mutations in early-onset familial Alzheimer's disease. Nature 1995, 375:754-760

5. Rogaev El, Sherrington R, Rogaeva EA, Levesque G, Ikeda M, Liang Y, Chi H, Lin C, Holman K, Tsuda T, et al: Familial Alzheimer's disease in kindreds with missense mutations in a gene on chromosome 1 related to the Alzheimer's disease type 3 gene. Nature 1995, 376:775-778.

6. Saunders AM, Strittmatter WJ, Schmechel D, George-Hyslop PH, PericakVance MA, Joo SH, Rosi BL, Gusella JF, Crapper-MacLachlan DR, Alberts MJ, et al: Association of apolipoprotein E allele epsilon 4 with late-onset familial and sporadic Alzheimer's disease. Neurology 1993, 43:1467-1472.

7. Frautschy SA, Baird A, Cole GM: Effects of injected Alzheimer betaamyloid cores in rat brain. Proc Natl Acad Sci USA 1991, 88:8362-8366.

8. Kowall NW, Beal MF, Busciglio J, Duffy LK, Yankner BA: An in vivo model for the neurodegenerative effects of beta amyloid and protection by substance P. Proc Natl Acad Sci USA 1991, 88:7247-7251.

9. Behl C, Davis JB, Klier FG, Schubert D: Amyloid beta peptide induces necrosis rather than apoptosis. Brain Res 1994, 645:253-264.

10. Loo DT, Copani A, Pike CJ, Whittemore ER, Walencewicz AJ, Cotman CW: Apoptosis is induced by beta-amyloid in cultured central nervous system neurons. Proc Natl Acad Sci USA 1993, 90:7951-7955.

11. Busser J, Geldmacher DS, Herrup K: Ectopic cell cycle proteins predict the sites of neuronal cell death in Alzheimer's disease brain. J Neurosci 1998, 18:2801-2807.
12. Liu WK, Williams RT, Hall FL, Dickson DW, Yen SH: Detection of a Cdc2related kinase associated with Alzheimer paired helical filaments. Am J Pathol 1995, 146:228-238.

13. McShea A, Harris PL, Webster KR, Wahl AF, Smith MA: Abnormal expression of the cell cycle regulators P16 and CDK4 in Alzheimer's disease. Am J Pathol 1997, 150:1933-1939.

14. Vincent I, Jicha G, Rosado M, Dickson DW: Aberrant expression of mitotic cdc2/cyclin B1 kinase in degenerating neurons of Alzheimer's disease brain. J Neurosci 1997, 17:3588-3598.

15. Copani A, Uberti D, Sortino MA, Bruno V, Nicoletti F, Memo M: Activation of cell-cycle-associated proteins in neuronal death: a mandatory or dispensable path? Trends Neurosci 2001, 25-31.

16. Ogawa O, Lee HG, Zhu X, Raina A, Harris PL, Castellani RJ, Perry G, Smith MA: Increased p27, an essential component of cell cycle control, in Alzheimer's disease. Aging Cell 2003, 2:105-110.

17. Evans TA, Raina AK, Delacourte A, Aprelikova O, Lee HG, Zhu X, Perry G, Smith MA: BRCA1 may modulate neuronal cell cycle re-entry in Alzheimer disease. Int J Med Sci 2007, 140-145.

18. Cenini G, Sultana R, Memo M, Butterfield DA: Effects of oxidative and nitrosative stress in brain on p53 proapoptotic protein in amnestic mild cognitive impairment and Alzheimer disease. Free Radic Biol Med 2008, 45:81-85.

19. Hsiao K, Chapman P, Nilsen S, Eckman C, Harigaya Y, Younkin S, Yang F, Cole G: Correlative memory deficits, Abeta elevation, and amyloid plaques in transgenic mice. Science 1996, 274:99-102.

20. Yang Y, Varvel NH, Lamb BT, Herrup K: Ectopic cell cycle events link human Alzheimer's disease and amyloid precursor protein transgenic mouse models. J Neurosci 2006, 26:775-784.

21. Lopes JP, Oliveira CR, Agostinho P: Cdk5 acts as a mediator of neuronal cell cycle re-entry triggered by amyloid-beta and prion peptides. Cell Cycle 2009, 8:97-104.

22. Wersto RP, Cardozo-Pelaez F, Smilenov L, Chan SL, Chrest FJ, Emokpae R Jr, Gorospe M, Mattson MP: Cell cycle activation linked to neuronal cell death initiated by DNA damage. Neuron 2004, 41:549-561.

23. Miura Y, Tam T, Ido A, Morinaga T, Miki T, Hashimoto T, Tamaoki T: Cloning and characterization of an ATBF1 isoform that expresses in a neuronal differentiation-dependent manner. J Biol Chem 1995, 270:26840-26848.

24. Morinaga T, Yasuda H, Hashimoto T, Higashio K, Tamaoki T: A human alpha-fetoprotein enhancer-binding protein, ATBF1, contains four homeodomains and seventeen zinc fingers. Mol Cell Biol 1991, 11:6041-6049.

25. Jung CG, Kim HJ, Kawaguchi M, Khanna KK, Hida H, Asai K, Nishino H, Miura Y: Homeotic factor ATBF1 induces the cell cycle arrest associated with neuronal differentiation. Development 2005, 132:5137-5145.

26. Matsuoka S, Ballif BA, Smogorzewska A, McDonald ER, Hurov KE, Luo J, Bakalarski CE, Zhao Z, Solimini N, Lerenthal Y, et al: ATM and ATR substrate analysis reveals extensive protein networks responsive to DNA damage. Science 2007, 316:1160-1166.

27. Miura Y, Kataoka H, Joh T, Tada T, Asai K, Nakanishi M, Okada N, Okada H: Susceptibility to killer $T$ cells of gastric cancer cells enhanced by Mitomycin-C involves induction of ATBF1 and activation of p21 (Waf1/ Cip1) promoter. Microbiol Immunol 2004, 48:137-145.

28. Sun X, Frierson HF, Chen C, Li C, Ran Q, Otto KB, Cantarel BL, Vessella RL, Gao AC, Petros J, et al: Frequent somatic mutations of the transcription factor ATBF1 in human prostate cancer. Nat Genet 2005, 37:407-412.

29. Dong XY, Sun X, Guo P, Li Q, Sasahara M, Ishii Y, Dong JT: ATBF1 inhibits ER function by selectively competing with AIB1 for binding to ER in ERpositive breast cancer cells. J Biol Chem 285(43):32801-9.

30. Kawarabayashi T, Younkin LH, Saido TC, Shoji M, Ashe KH, Younkin SG: Agedependent changes in brain, CSF, and plasma amyloid (beta) protein in the Tg2576 transgenic mouse model of Alzheimer's disease. J Neurosci 2001, 21:372-381.

31. Kamiguchi $\mathrm{Y}$, Tateno H: Radiation- and chemical-induced structural chromosome aberrations in human spermatozoa. Mutat Res 2002, 504:183-191.

32. Roth KA: Caspases, apoptosis, and Alzheimer disease: causation, correlation, and confusion. J Neuropathol Exp Neurol 2001, 60:829-838

33. Bryant HE, Helleday T: Inhibition of poly (ADP-ribose) polymerase activates ATM which is required for subsequent homologous recombination repair. Nucleic Acids Res 2006, 34:1685-1691. 
34. Tang D, Wu D, Hirao A, Lahti JM, Liu L, Mazza B, Kidd VJ, Mak TW, Ingram AJ: ERK activation mediates cell cycle arrest and apoptosis after DNA damage independently of p53. J Biol Chem 2002, 277:12710-12717.

35. Greene LA, Biswas SC, Liu DX: Cell cycle molecules and vertebrate neuron death: E2F at the hub. Cell Death Differ 2004, 11:49-60.

36. Herrup K, Neve R, Ackerman SL, Copani A: Divide and die: cell cycle events as triggers of nerve cell death. J Neurosci 2004, 24:9232-9239.

37. Nunomura A, Moreira PI, Lee HG, Zhu X, Castellani RJ, Smith MA, Perry G: Neuronal death and survival under oxidative stress in Alzheimer and Parkinson diseases. CNS Neurol Disord Drug Targets 2007, 6:411-423.

38. Rashidian J, lyirhiaro GO, Park DS: Cell cycle machinery and stroke. Biochim Biophys Acta 2007, 1772:484-493.

39. Keramaris E, Hirao A, Slack RS, Mak TW, Park DS: Ataxia telangiectasiamutated protein can regulate $\mathrm{p} 53$ and neuronal death independent of Chk2 in response to DNA damage. J Biol Chem 2003, 278:37782-37789.

40. Krantic S, Mechawar N, Reix S, Quirion R: Molecular basis of programmed cell death involved in neurodegeneration. Trends Neurosci 2005, 28:670-676.

41. Kurz EU, Lees-Miller SP: DNA damage-induced activation of ATM and ATM-dependent signaling pathways. DNA Repair (Amst) 2004, 3:889-900.

42. Ljungman M: Activation of DNA damage signaling. Mutat Res 2005, 577:203-216.

43. McKinnon PJ: Ataxia telangiectasia: new neurons and ATM. Trends Mol Med 2001, 7:233-234

44. Uberti D, Ferrari Toninelli G, Memo M: Involvement of DNA damage and repair systems in neurodegenerative process. Toxicol Lett 2003, 139:99-105.

45. Michikawa M, Gong JS, Fan QW, Sawamura N, Yanagisawa K: A novel action of alzheimer's amyloid beta-protein (Abeta): oligomeric Abeta promotes lipid release. J Neurosci 2001, 21:7226-7235.

46. Ziv Y, Jaspers NG, Etkin S, Danieli T, Trakhtenbrot L, Amiel A, Ravia Y, Shiloh Y: Cellular and molecular characteristics of an immortalized ataxia-telangiectasia (group AB) cell line. Cancer Res 1989, 49:2495-2501.

47. Ziv Y, Bar-Shira A, Pecker I, Russell P, Jorgensen TJ, Tsarfati I, Shiloh Y: Recombinant ATM protein complements the cellular A-T phenotype. Oncogene 1997, 15:159-167.

48. Nojiri S, Joh T, Miura Y, Sakata N, Nomura T, Nakao H, Sobue S, Ohara H, Asai $\mathrm{K}$, Ito M: ATBF1 enhances the suppression of STAT3 signaling by interaction with PIAS3. Biochem Biophys Res Commun 2004, 314:97-103.

doi:10.1186/1750-1326-6-47

Cite this article as: Jung et al:: Beta-amyloid increases the expression level of ATBF1 responsible for death in cultured cortical neurons.

Molecular Neurodegeneration 2011 6:47.

\section{Submit your next manuscript to BioMed Central and take full advantage of:}

- Convenient online submission

- Thorough peer review

- No space constraints or color figure charges

- Immediate publication on acceptance

- Inclusion in PubMed, CAS, Scopus and Google Scholar

- Research which is freely available for redistribution 